\title{
Heavy metal dissolution mechanisms from electrical industrial sludge
}

\author{
Viraj Gunarathne a , Anushka Upamali Rajapaksha ${ }^{\mathrm{a}, \mathrm{b}, *}$, Meththika Vithanage ${ }^{\mathrm{a}, \mathrm{b}}$, Nadeesh Adassooriya , \\ Asitha Cooray ${ }^{\mathrm{b}, \mathrm{d}}$, Sudantha Liyanage ${ }^{\mathrm{d}}$, Bandunee Athapattu ${ }^{\mathrm{e}}$, Nishanta Rajakaruna ${ }^{\mathrm{g}, \mathrm{h}}$, \\ Avanthi Deshani Igalavithana ${ }^{\mathrm{f}}$, Deyi Hou ${ }^{\mathrm{i}}$, Daniel S. Alessi ${ }^{\mathrm{j}}$, Yong Sik Ok ${ }^{\mathrm{f}, * *}$ \\ a Ecosphere Resilience Research Centre, Faculty of Applied Sciences, University of Sri Jayewardenepura, Sri Lanka \\ b Instrument Centre, Faculty of Applied Sciences, University of Sri Jayewardenepura, Sri Lanka \\ c Department of Food Science and Technology, Wayamba University of Sri Lanka, Makandura, Gonawila 60170, Sri Lanka \\ d Department of Chemistry, Faculty of Applied Sciences, University of Sri Jayewardenepura, Sri Lanka \\ e Department of Civil Engineering, The Open University of Sri Lanka, Nawala, Nugegoda, Sri Lanka \\ ${ }^{\mathrm{f}}$ Korea Biochar Research Center E' Division of Environmental Science and Ecological Engineering, Korea University, Seoul 02841, Republic of Korea \\ ${ }^{g}$ Biological Sciences Department, California Polytechnic State University, San Luis Obispo, CA 93407, USA

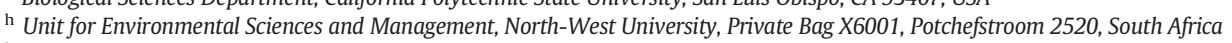 \\ i School of Environment, Tsinghua University, Beijing 100084, China \\ j Department of Earth and Atmospheric Sciences, University of Alberta, AB T6G 2E3, Canada
}

\section{H I G H L I G H T S}

- Metal release of electrical industrial sludge via acid leaching has been studied.

- Efficiency of leaching depends on the characteristics of sludge and the acid type.

- Metal release from sludge is facilitated by proton- and ligand-promoted mechanisms.

- Inorganic acids containing ligands can increase the leaching efficiency of metals.

\section{G R A P H I C A L A B S T R A C T}

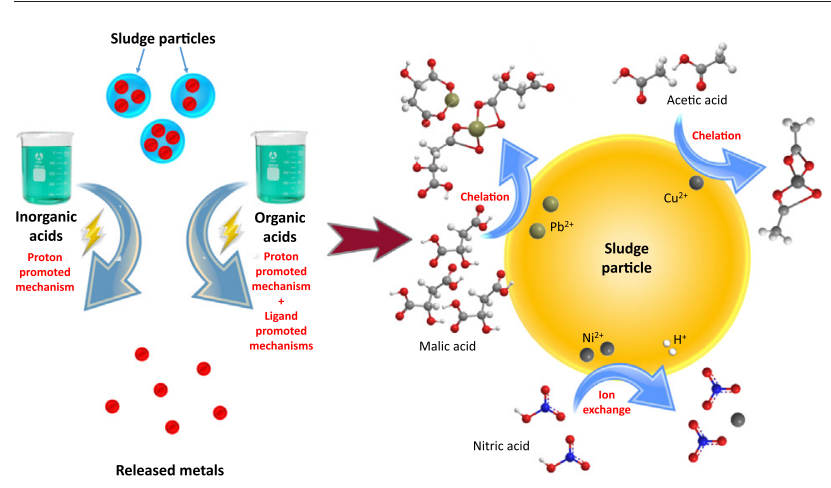

\begin{abstract}
A B S T R A C T
In this paper, we investigate the release of heavy metals from sludge produced from an electrical industry using both organic and inorganic acids. Single and sequential extractions were conducted to assess heavy metals in different phases of the sludge. Metal release from sludge was investigated in the presence of three inorganic acids (nitric, sulfuric, and phosphoric) and three organic acids (acetic, malic, and citric) at concentrations ranging from 0.1 to $2.0 \mathrm{~mol} \mathrm{~L}^{-1}$. Sequential extraction indicated the presence of $\mathrm{Cu}$ primarily in the carbonate fraction, $\mathrm{Pb}$ in the residual fraction, and $\mathrm{Ni}$ in the $\mathrm{Fe}-\mathrm{Mn}$ oxide fraction. The cumulative release rates of heavy metals (i.e., $\mathrm{Pb}, \mathrm{Cu}$, and $\mathrm{Ni}$ ) by $1.0 \mathrm{~mol} \mathrm{~L}^{-1}$ of acid increased with the use of the following acids in the order of: malic $<$ sulfuric $<$ acetic $<$ phosphoric $<$ citric $<$ nitric. Acetic acid exhibited the highest release of $\mathrm{Cu}$, at a rate of $72.62 \times 10^{-11} \mathrm{~mol} \mathrm{~m}^{-2} \mathrm{~s}^{-1}$ at $\mathrm{pH} 1$, and malic acid drove the release of $\mathrm{Pb}$ at a maximum rate of $3.90 \times 10^{-11} \mathrm{~mol} \mathrm{~m}^{-2} \mathrm{~s}^{-1}$. Meanwhile, nitric acid provided the maximum rate of Ni release $\left(0.23 \times 10^{-11} \mathrm{~mol} \mathrm{~m}^{-2} \mathrm{~s}^{-1}\right)$ at $\mathrm{pH} 1$. The high rate of metal release

by organic acids is explained through ligand-promoted mechanisms that enhance the release of metal ions from
\end{abstract}

Keywords:

Trace metals

Resource recovery

Sludge treatment

\footnotetext{
* Correspondence to: A.U. Rajapaksha, Ecosphere Resilience Research Centre, Faculty of Applied Sciences, University of Sri Jayewardenepura, Sri Lanka.

** Correspondence to: Y.S. Ok, Korea Biochar Research Center \& Division of Environmental Science and Ecological Engineering, Korea University, Seoul 02841, Republic of Korea E-mail addresses: anurajapaksha@sjp.ac.lk (A.U. Rajapaksha), yongsikok@korea.ac.kr (Y.S. Ok).
} 


\section{Introduction}

The accelerated development of industries has contributed to increased generation of contaminants-containing waste. For example, the electrical appliance industry is known to produce large amounts of waste that contain heavy metals (Hossain et al., 2015; Pérez-Belis et al., 2015; Terazono et al., 2006). However, among various types of industrial waste, sludge has been recognized as one of the most challenging to treat (Barakat, 2011; Ghorpade and Ahammed, 2017; Ried, 1988; Tsai et al., 2009). Most of the industrial sludge types are resistant to biodegradation as a result of their low solubility, non-optimal $\mathrm{C} / \mathrm{N}$ ratio, and presence of high amounts of toxic heavy metals (Azbar et al., 2008). Therefore, landfill disposal is most widely used to handle industrial sludge, although it is not an environmentally friendly approach (Huyen et al., 2016). Nevertheless, anaerobic and aerobic digestion, vacuum filtration, elutriation, use of drying beds and sludge lagoons, wet combustion, atomized suspension, drying and incineration, and centrifugation are widely practiced treatment methods that involve reducing the quantity of final sludge prior to disposal into the ocean (sludge barging) or sanitary landfills (Nemerow, 2010; Al-Harahsheh et al., 2018; Lobato et al., 2015). As an example, galvanic sludge, which is generally produced by the precipitation of rinsing water and spent electrolytes in electrical and electroplating industries, exceeds $1,000,000$ metric tons of global waste generation per year (Silva et al., 2008; Ghorpade and Ahammed, 2017). Industrial sludge contains elevated concentrations of heavy metals, particularly $\mathrm{Cr}, \mathrm{Ni}, \mathrm{Zn}, \mathrm{Cu}$, and $\mathrm{Pb}$ (Cui et al., 2010). The release of heavy metals into the natural environment through the direct disposal of non-treated or partially treated industrial waste may contribute to human and ecosystem health risks (Tou et al., 2017; Pecht et al., 2018). Therefore, selecting a proper method to treat industrial sludge before disposal is mandatory.

The increasing global demand for metals makes metal recovery from readily-available and continuously generated secondary resources and waste more appealing as compared to treatment and landfill disposal (Shemi et al., 2015). As a result, various kinds of alternative pyro and hydrometallurgical techniques, including bioleaching, alkaline leaching, and acid leaching, as well as combinations of these techniques are increasingly utilized (Seidel et al., 2001; Habashi, 2005; Shemi et al., 2015; Yao et al., 2014). However, pyrometallurgical techniques are associated with disadvantages and limitations due to high energy consumption and the poor quality of end products (Medi et al., 2006).

Among the methods currently in use, acid leaching is commonly utilized for heavy metal recovery due to its wide applicability. Sulfuric acid leaching has been effectively utilized together with electrowinning to recover $\mathrm{Cu}$ from galvanic sludge (Huyen et al., 2016). The study by Huyen et al. (2016) emphasized that the use of acid for leaching is more cost effective and efficient than leaching with bases. Vemic et al. (2016) focused on the recovery of heavy metals (i.e., Mo, Ni, and Co) from sludge generated from recycling plants, using several concentrated acids, including sulfuric, nitric, and hydrochloric acids, as well as an acid combination. The greatest recovery of metals resulted from concentrated sulfuric acid, reflecting its capability for leaching due to its strong oxidizing capacity as a diacidic compound. Alternately, Walawalkar et al. (2016) used sulfuric, nitric, and hydrochloric acids to recover rare earth elements from phosphogypsum and found that nitric and hydrochloric acids exhibited better leaching than sulfuric acid. The leaching efficiency is not only dependent on the type of acid used but also on the type of the raw material or waste used. Although many studies to date have investigated the capacity of inorganic acids for acid leaching, experiments with organic acids are limited (Zhou et al., 2017; Battsengel et al., 2018; Liu et al., 2016). The studies of Hamer et al. (2003) and Rajapaksha et al. (2012) highlight the usability of organic acids for the dissolution of metals from minerals by increasing the rate of dissolution by both ligand-promoted and proton-promoted mechanisms.

As a developing country, industries in Sri Lanka make only minimal efforts for treatment of generated waste due to lack of treatment facilities and associated costs. The electrical appliances industries in Sri Lanka generate large quantities of heavy metal rich sludge. However, the limited availability of treatment facilities leads to the discharge of this sludge directly into surrounding habitats, including wetlands, posing serious threats to the environment and human health (Anjithan et al., 2015). Treating heavy metal-rich waste by acid leaching could be the best option for a developing country like Sri Lanka, because it involves the recovery of heavy metals alongside detoxification. However, industrial sludge types widely vary in terms of physicochemical characteristics, influencing the effectiveness of the treatment methods and processes. Further, due to the variation in chemical composition of various industrial sludges, the effectiveness of different types of acids for acid leaching may also vary. In this regard, an understanding of the types of metals present in the sludge and their fractionation among the different phases of sludge is useful in adopting the most suitable acid type for leaching. Additionally, an understanding of the mechanisms involved in the metal release from sludge can better inform the best and most cost-effective acid treatments for metal recovery. Therefore, the main objectives of this study are to 1) characterize the sludge, 2) determine the release rate of $\mathrm{Cu}, \mathrm{Pb}$ and $\mathrm{Ni}$ by three organic and three inorganic acids to find out the most effective leaching solution, and 3) describe the mechanisms involved in the release of metals.

\section{Material and methods}

Electrical industrial sludge was collected from the wastewater treatment plant of one of the leading electrical product manufacturing companies in Western Province, Sri Lanka. The sludge was dried at ambient temperature $\left(25-27^{\circ} \mathrm{C}\right)$, mechanically crushed, and sieved through a 1mm mesh.

\subsection{Characterization of sludge}

Chemical parameters, including $\mathrm{pH}$, electrical conductivity (EC), available nitrogen and phosphorus, percentage of total organic carbon (TOC), and cation exchange capacity (CEC) were analyzed using the standard procedures presented in Anderson and Ingram (1989). The $\mathrm{pH}$ and $\mathrm{EC}$ of electrical industrial sludge were determined by analyzing the sludge in liquid suspension with deionized water at a 1:10 ratio. Plant-available nitrogen, phosphorus, and \%TOC were estimated by colorimetric methods. To measure the CEC of electrical industrial sludge, an extraction of ammonium acetate was used. From the sludge, $2.0 \mathrm{~g}$ was shaken with $20 \mathrm{~mL}$ of ammonium acetate solution for $15 \mathrm{~min}$ at $100 \mathrm{rpm}$, and the solution was filtered through a $0.45-\mu \mathrm{m}$ syringe filter. The filtrate was analyzed for $\mathrm{Na}, \mathrm{K}, \mathrm{Ca}$, and Mg using inductively coupled plasma optical emission spectroscopy (ICP-OES) (iCAP 7600 ICP-OES), and the CEC value for electrical industrial sludge was calculated. 
Scanning electron microscopy (Hitachi SU6600 Analytical Variable Pressure FE-SEM) was employed to analyze the surface characteristics of sludge particles. Energy-dispersive X-ray spectroscopy (SEM/EDS) was carried out to determine the elemental composition of electrical sludge sample using the same scanning electron microscope.

The structural mineralogy of the sludge sample was determined by the powder X-ray diffraction (PXRD) technique (Rigaku, Ultima IV-Japan). The PXRD patterns were obtained from $\mathrm{Cu} \mathrm{K \alpha}$ radiation at a wavelength of $1.54056 \AA$ at $40 \mathrm{~mA}$ and $40 \mathrm{kV}$, scanning the range between 2 and $65^{\circ}(2 \theta)$. Fourier transform infrared spectrophotometry (FTIR), using the Thermo Scientific NICOLET iS10 (USA), was utilized to determine functional moieties present in the sludge particles. FTIR transmission mode was utilized to collect spectra between wavenumbers $4000-400 \mathrm{~cm}^{-1}$ at a resolution of $4 \mathrm{~cm}^{-1}$ and using 64 repeat scans. The Brunauer-Emmett-Teller (BET) method was employed to estimate the specific surface area of electrical industrial sludge.

\subsection{Chemical extractions}

\subsubsection{Diethylene triaminepentaacetic acid (DTPA) extraction}

The DTPA extraction method was utilized to determine the DTPA extractable concentrations of heavy metals, as this extraction is wellsuited to determine the plant bioavailable fraction of metals in soil and sediments (Rajapaksha et al., 2012). A total of $20.0 \mathrm{~mL}$ of $0.005 \mathrm{~mol} \mathrm{~L}^{-1}$ DTPA and $0.01 \mathrm{~mol} \mathrm{~L}^{-1} \mathrm{CaCl}_{2}$ in $0.1 \mathrm{~mol} \mathrm{~L}^{-1}$ triethanolamine solution of $\mathrm{pH} 7.30$ was used to extract metals from $10.0 \mathrm{~g}$ of air-dried electrical industrial sludge. The solution was shaken for $2 \mathrm{~h}$ at $100 \mathrm{rpm}$ and filtered through a $0.45-\mu \mathrm{m}$ syringe filter. The bioavailable concentrations of metals in extracted solution were quantified by ICP-OES (iCAP 7600 ICP-OES).

\subsubsection{TCLP test}

The toxicity characteristic leaching procedure (TCLP) introduced by the United States Environmental Protection Agency (EPA) was employed to determine the ability of toxic metals in sludge to be released into the environment and groundwater. Extraction was done with TCLP extraction fluid \# $2(\mathrm{pH} 2.88 \pm 0.05)$ and a liquid:solid ratio of 20 in polypropylene tubes, using a rotary shaker for $18 \mathrm{~h}$ at 30 $\pm 2 \mathrm{rpm}$ at ambient temperature $\left(25-27^{\circ} \mathrm{C}\right)$. Solutions were filtered through $0.45-\mu \mathrm{m}$ syringe filters and analyzed by ICP-OES (iCAP 7600 ICP-OES) for metals.

\subsubsection{Sequential extractions of heavy metals}

Sequential extraction for sludge was done through five consecutive extractions (Tessier et al., 1979; Armienta et al., 1996). A sample of $1.0 \mathrm{~g}$ of air-dried sludge was taken for the initial extraction step.

\section{Extraction 1 (Exchangeable)}

The sludge sample was treated with $20.0 \mathrm{~mL}$ of $1 \mathrm{~mol} \mathrm{~L}^{-1}$ magnesium chloride solution ( $\mathrm{pH} 7.0$ ) with continuous agitation for $1 \mathrm{~h}$ at ambient temperature $\left(25-27^{\circ} \mathrm{C}\right)$.

\section{Extraction 2 (Bound to carbonates)}

Residue that resulted from Extraction 1 was leached with $20.0 \mathrm{~mL}$ of $1 \mathrm{~mol} \mathrm{~L}^{-1}$ sodium acetate (adjusted to $\mathrm{pH} 5.0$ with acetic acid) for $2 \mathrm{~h}$ at ambient temperature $\left(25-27^{\circ} \mathrm{C}\right)$ with continuous agitation.

Extraction 3 (Bound to $\mathrm{Fe}-\mathrm{Mn}$ oxide)

Residue from Extraction 2 was reacted with $20.0 \mathrm{~mL}$ of $0.04 \mathrm{~mol} \mathrm{~L}^{-1}$ hydroxylamine hydrochloride in $25 \%(\mathrm{v} / \mathrm{v})$ acetic acid with slow and continuous agitation at $90{ }^{\circ} \mathrm{C}$ for $2 \mathrm{~h}$.
Extraction 4 (Bound to organic matter)

Residue from Extraction 3 was treated with $3.0 \mathrm{~mL}$ of $0.02 \mathrm{~mol} \mathrm{~L}^{-1}$ nitric acid and $5.0 \mathrm{~mL}$ of $30 \%$ hydrogen peroxide, which was adjusted to $\mathrm{pH} 2$ with the addition of nitric acid. The solution was heated at $85{ }^{\circ} \mathrm{C}$ for $2 \mathrm{~h}$ with occasional stirring. Then, a $3.0 \mathrm{~mL}$ aliquot of $30 \%$ hydrogen peroxide at $\mathrm{pH} 2$ was transferred to the same solution and heated to $85^{\circ} \mathrm{C}$ with intermittent agitation for $3 \mathrm{~h}$. Afterwards, the solution was maintained at ambient temperature $\left(25-27^{\circ} \mathrm{C}\right)$, and $5.0 \mathrm{~mL}$ of $3.2 \mathrm{~mol} \mathrm{~L}^{-1}$ ammonium acetate in $20 \%(\mathrm{v} / \mathrm{v})$ nitric acid was mixed. Then, the solution was diluted to $20.0 \mathrm{~mL}$, with continuous agitation.

Extraction 5 (Residual)

From the Extraction 4 residue, $0.2 \mathrm{~g}$ was digested by a microwave digester with $4.0 \mathrm{~mL}$ of concentrated nitric acid.

After each successive extraction, the solution was centrifuged for $15 \mathrm{~min}$ at $3500 \mathrm{rpm}$, and the supernatant was filtered through 0.45 $\mu \mathrm{m}$ syringe filters and analyzed for metals using ICP-OES (iCAP 7600 ICP-OES).

\subsection{Heavy metal dissolution with organic and inorganic acids}

Acid leaching was done in batch experiments using three inorganic (i.e., nitric, sulfuric, and phosphoric) and three organic (i.e., acetic, malic, and citric) acids. Among the six acids, nitric and acetic are monobasic, sulfuric and malic are dibasic and phosphoric and citric are tribasic. These different acids were selected for leaching experiments in order to determine their effectiveness for heavy metal dissolution and to uncover related mechanisms. All metals were analyzed after the extraction step with ICP-OES (iCAP 7600 ICP-OES).

\subsubsection{Solid to liquid ratio}

To find the most suited solid to liquid (S/L) ratio for heavy metal recovery from sludge, $2 \mathrm{~mol} \mathrm{~L}^{-1}$ sulfuric and malic acid solutions were used. Three $\mathrm{S} / \mathrm{L}$ ratios of 20,60 , and $100 \mathrm{~g} \mathrm{~L}^{-1}$ were employed. All the solutions were shaken with a linear shaker at $100 \mathrm{rpm}$ at ambient temperature $\left(25-27^{\circ} \mathrm{C}\right)$ for $12 \mathrm{~h}$.

\subsubsection{Release rate and $\mathrm{pH}$ dependency}

Five concentrations (i.e., $0.1,0.5,1.0,1.5$, and $2.0 \mathrm{~mol} \mathrm{~L}^{-1}$ ) for each of the six acids were made and extractions were done with each sample of sludge using an $\mathrm{S} / \mathrm{L}$ ratio of $20 \mathrm{~g} \mathrm{~L}^{-1}$, which was determined to be the optimal S/L ratio from previous experiments. Each leachate was filtered through $0.45 \mu \mathrm{m}$ filters after shaking for $12 \mathrm{~h}$ at $100 \mathrm{rpm}$ at ambient temperature $\left(25-27^{\circ} \mathrm{C}\right)$. All the filtrated samples were analyzed with ICP-OES (iCAP 7600 ICP-OES) to find out the released concentrations of metals.

The methodology described in Hamer et al. (2003) was incorporated to evaluate the rate of release of $\mathrm{Pb}, \mathrm{Cu}$, and $\mathrm{Ni}$ from sludge with varying concentrations of organic and inorganic acids.

$R_{T}=K_{T} a_{\text {acid }}^{n_{T}}$

where $R_{T}\left(\mathrm{~mol} \mathrm{~m}^{-2} \mathrm{~s}^{-1}\right.$ ) is the total rate of metal dissolution with the action of a particular acid, $K_{T}\left(\mathrm{~mol} \mathrm{~m}^{-2} \mathrm{~s}^{-1}\right)$ is the rate constant of the particular acid, $n$ is the experimentally determined reaction factor, and $a$ is the activity of the particular acid, based on its concentration.

Similarly, Eq. (2) was used to evaluate the pH dependency of the release rate of the total $\mathrm{Pb}, \mathrm{Cu}$, and $\mathrm{Ni}$ by a particular acid with the same variables as in Eq. (1).

$\log R_{T}=\log k_{\mathrm{T}}-n_{T} p H$ 
Table 1

Chemical properties and elemental composition ${ }^{\mathrm{a}}$ of electrical industrial sludge.

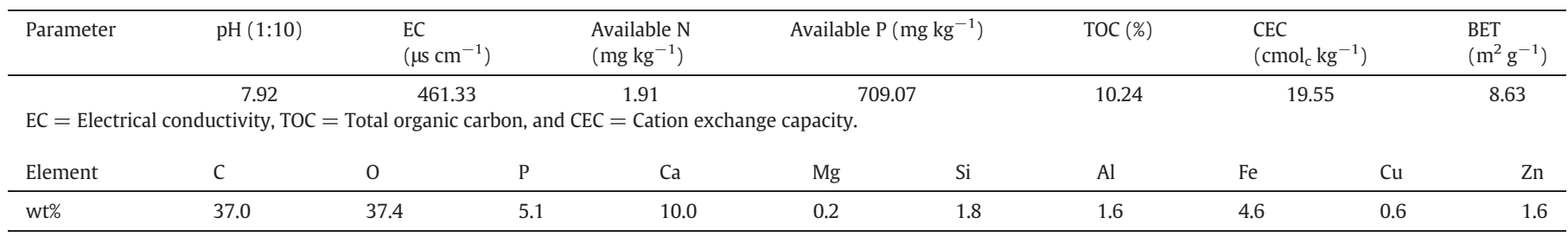

a Elemental composition was obtained from SEM/EDS.

\section{Results and discussion}

\subsection{Characterization of the sludge}

Table 1 summarizes the basic chemical characteristics of electrical industrial sludge. The sludge was slightly alkaline in nature, and this probably resulted from the pretreatment of sludge before release from the industrial wastewater treatment plant or due to presence of carbonate compounds.

The electrical industrial sludge consists of heterogeneous particles, as revealed by SEM images (Fig. 1a(i)). The uneven surfaces of large sludge aggregates were comprised of nano-range $(<100 \mathrm{~nm})$ unorganized, minute particles (Fig. 1a(ii)).

The SEM/EDS results also provide elemental composition data of the sludge (Fig. 1b). The electrical industrial sludge was primarily composed of carbon, oxygen, and calcium (37.0, 37.4, and $10.0 \mathrm{wt} \%$, respectively), while $\mathrm{P}, \mathrm{Mg}, \mathrm{Si}, \mathrm{Al}, \mathrm{Fe}, \mathrm{Cu}$, and $\mathrm{Zn}$ were also present (Table 1). The presence of a relatively high weight percentage of $C$ in the SEM/EDS results reveals the occurrence of organic compounds, which is also supported by the high percentage of total organic carbon observed in the sludge (Table 1 ). In addition, the occurrence of a high weight percentage of $\mathrm{C}$ and $\mathrm{Ca}$ indicates the existence of $\mathrm{CaCO}_{3}$, which may have contributed to the slight alkalinity of sludge.

The Fig. 2(a) reveals the PXRD pattern that was obtained for electrical industrial sludge. The peaks at $21.94^{\circ}, 39.32^{\circ}$ and $47.45^{\circ} 2 \theta$ indicate $\mathrm{Zn}$ in the form of $\mathrm{Zn}(\mathrm{OH})_{2}$; peak at $29.423^{\circ} 2 \theta$ for PbO; peaks at $32.29^{\circ}$ and $36.55^{\circ} 2 \theta$ for $\mathrm{PbO}_{2}$ and the peaks obtained at $26.64^{\circ}$ and $43.148^{\circ}$ $2 \theta$ are attributed to $\mathrm{Fe}$ in the form of $\mathrm{Fe}_{2} \mathrm{O}_{3}$. Furthermore, the presence of rare paramelaconite $\left(\mathrm{Cu}_{4} \mathrm{O}_{3}\right)$ is indicated by the peak at $43.14^{\circ} 2 \theta$. Moreover, the intense PXRD pattern at $29.423^{\circ} 2 \theta$ and peaks at $36.55^{\circ}$ and $39.39^{\circ} 2 \theta$ show the presence of $\mathrm{CaCO}_{3}$ and peaks at $20.64^{\circ}$ and $33.07^{\circ} 2 \theta$ indicate $\mathrm{SiO}_{2}$.
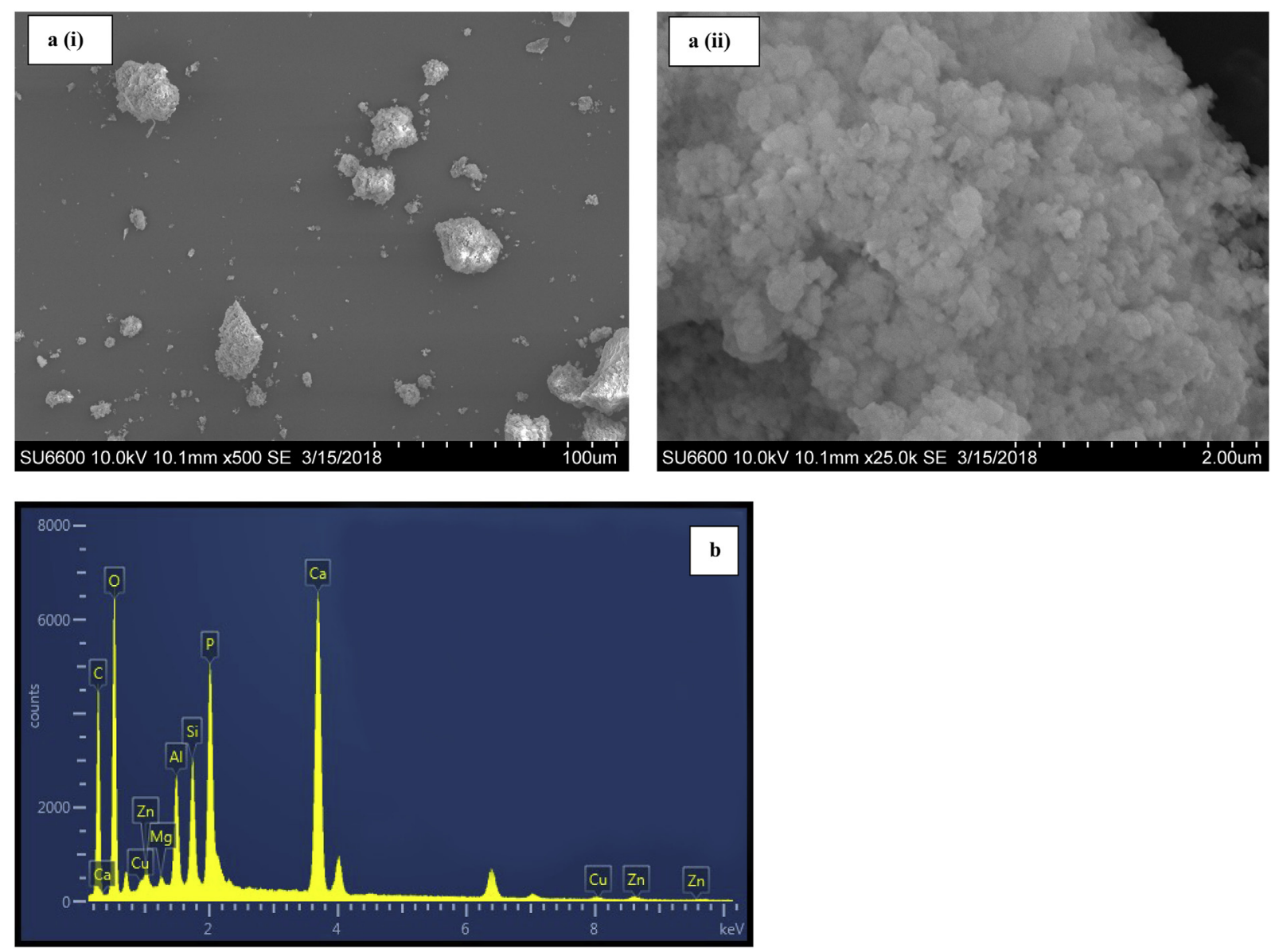

Fig. 1. SEM images (a) and SEM/EDS pattern (b) of electrical industrial sludge; magnification of (i) $\times 500$ and (ii) $\times 25,000$. 

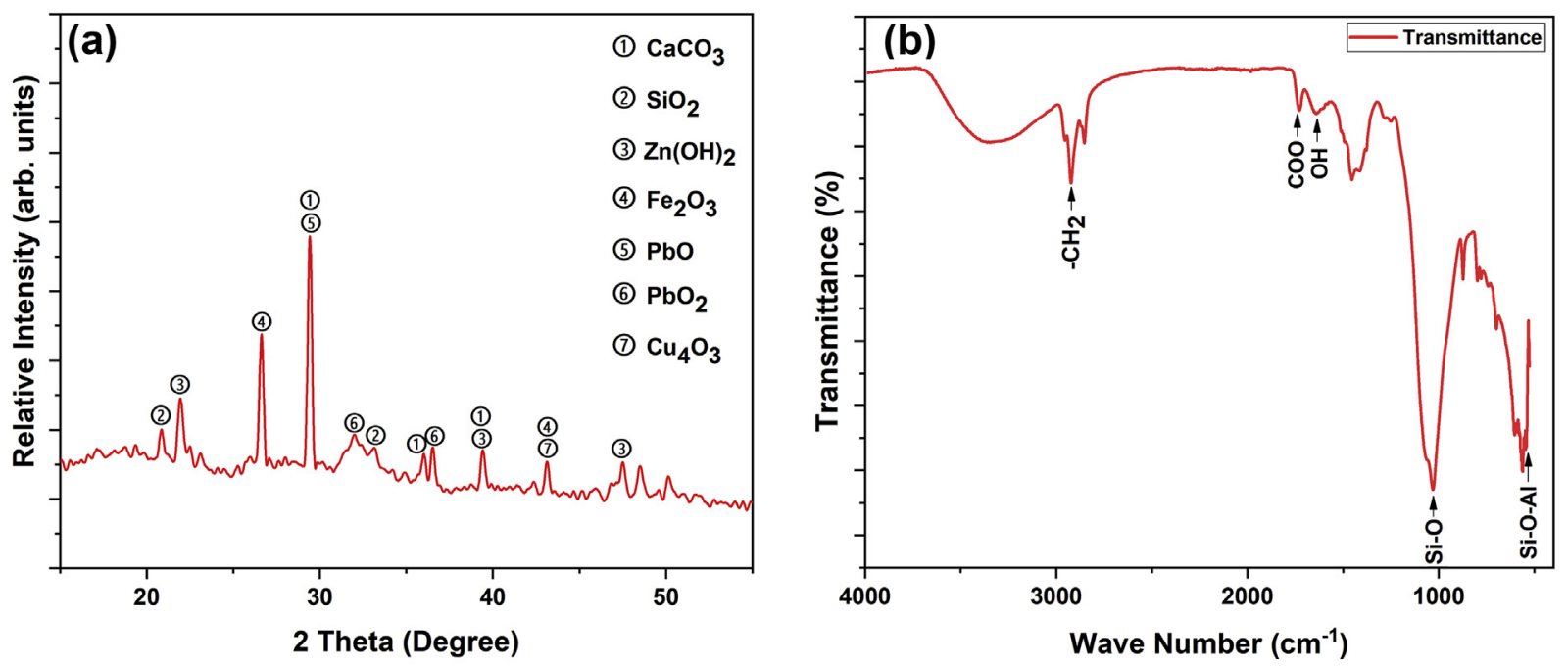

Fig. 2. (a) PXRD patterns and (b) FTIR spectrum for electrical industrial sludge.

The deep band at approximately $1030 \mathrm{~cm}^{-1}$ in the infrared spectrum of electrical industrial sludge (Fig. 2b) indicates the symmetric and antisymmetric stretching of $\mathrm{Si}-\mathrm{O}$ bonds, among tetrahedral groups (Barrera et al., 2017). The small band at $542 \mathrm{~cm}^{-1}$ represents the presence of the Si-O-Al bond (Tireli et al., 2015). Similarly, the small band pattern at $1642 \mathrm{~cm}^{-1}$ indicates the stretching and bending vibrations of OH (Wang et al., 2018). Moreover, the band at $2922 \mathrm{~cm}^{-1}$ is generated by $-\mathrm{CH}_{2}$, and that at $1727 \mathrm{~cm}^{-1}$ represent $\mathrm{COO}$ stretching (Lu et al., 2009), revealing that the sludge contains organic matter. Additionally, the broad band in the $3000-3700 \mathrm{~cm}^{-1}$ range represents the presence of moisture (Ali et al., 2015).

\subsection{Chemical extractions}

The results for single extraction procedures and sequential extractions of electrical industrial sludge are given in Table 2 . The highest DTPA extractable metal was $\mathrm{Cu}\left(298.7 \mathrm{mg} \mathrm{kg}^{-1}\right.$ ), whereas the lowest extractable concentration was reported for $\mathrm{Ni}$ (1.8 $\mathrm{mg} \mathrm{kg}^{-1}$ ). The DTPA extractable $\mathrm{Pb}$ concentration was $2.3 \mathrm{mg} \mathrm{kg}^{-1}$, which was much less compared to the concentration of extractable $\mathrm{Cu}(0.78 \%)$. The DTPA extractable concentration expresses the amount of metal that is bioavailable for plant uptake ( $\mathrm{Li}$ et al., 2014). Meanwhile, the toxicity characteristic leaching

Table 2

Heavy metals distribution among different fractions of electrical industrial sludge.

\begin{tabular}{|c|c|c|c|c|}
\hline \multirow[t]{2}{*}{ Extractions } & \multirow[t]{2}{*}{ Fractions } & \multicolumn{3}{|c|}{ Amount released $^{\mathrm{a}}$} \\
\hline & & $\mathrm{Pb}$ & $\mathrm{Cu}$ & $\mathrm{Ni}$ \\
\hline \multicolumn{5}{|l|}{ Single extractions } \\
\hline 0.005 DTPA & Extractable & 2.3 & 298.7 & 1.8 \\
\hline TCLP extraction & Toxicity & 0.0 & 1.2 & 0.1 \\
\hline \multicolumn{5}{|l|}{ Sequential extractions } \\
\hline $1 \mathrm{~mol} \mathrm{~L}^{-1} \mathrm{MgCl}_{2}(\mathrm{pH} 7.0)$ & Exchangeable & ND & 24.5 & ND \\
\hline $1 \mathrm{~mol} \mathrm{~L}^{-1} \mathrm{NaOAc}(\mathrm{pH} 5.0)$ & Carbonates & 10.2 & 7401.0 & 18.3 \\
\hline $\begin{array}{l}0.04 \mathrm{~mol} \mathrm{~L}-1 \mathrm{NH}_{2} \mathrm{OH} \cdot \mathrm{HCl} \text { in } 25 \%(\mathrm{~V} / \mathrm{V}) \\
\mathrm{HOAc}\left(90^{\circ} \mathrm{C}\right)\end{array}$ & Fe-Mn oxides & 40.5 & 2939.1 & 20.2 \\
\hline $\begin{array}{l}0.02 \mathrm{~mol} \mathrm{~L}^{-1} \mathrm{HNO}_{3}, 30 \% \mathrm{H}_{2} \mathrm{O}_{2}\left(85^{\circ} \mathrm{C}\right) \text {, } \\
\quad 3.2 \mathrm{~mol} \mathrm{~L}^{-1} \mathrm{NH}_{4} \mathrm{OAc}\end{array}$ & Organic matter & 406.5 & 738.7 & ND \\
\hline $\mathrm{HF}, \mathrm{HClO}_{4}, \mathrm{HCl}$ & Residual/silicate & 800.6 & 281.2 & 5.2 \\
\hline Total concentration from (i) to (v) & & 1257.8 & $11,384.4$ & 43.8 \\
\hline
\end{tabular}

a Released amount of metals from all the extractions are represented in $\mathrm{mg} \mathrm{kg}^{-1}$, except concentration for TCLP extraction which is in $\mathrm{mg} \mathrm{L}^{-1}$. procedure (EPA: TCLP) helps determine the mobility of hazardous waste, both in organic and inorganic forms. Lead was not detected in the TCLP solution (Table 2). Although the TCLP extraction yielded concentrations of 1.2 and $0.1 \mathrm{mg} \mathrm{L}^{-1}$ for $\mathrm{Cu}$ and $\mathrm{Ni}$, respectively, neither was considered a RCRA-8, hazardous metal by the US EPA (1992). However, the leaching of $\mathrm{Cu}$ and $\mathrm{Ni}$, and their bioaccumulation in biota may pose a risk to human and ecosystem health (Brewer, 2010; Cui et al., 2010; Brocato and Costa, 2017).

In the sequential extraction, the total concentration of $\mathrm{Cu}$ from extraction (i) to (v) was $11,384.4 \mathrm{mg} \mathrm{kg}^{-1}$, while the total concentrations of $\mathrm{Pb}$ and $\mathrm{Ni}$ were $1257.8 \mathrm{mg} \mathrm{kg}^{-1}$ and $43.8 \mathrm{mg} \mathrm{kg}^{-1}$, respectively. Therefore, the content of $\mathrm{Cu}$ in electrical industrial sludge is nine times higher than that of $\mathrm{Pb}$ and 260 times higher than that of Ni. The maximum concentration of $\mathrm{Cu}\left(7401.0 \mathrm{mg} \mathrm{kg}^{-1}\right)$, which is $65 \%$ of the total concentration, was found in the carbonate-bound fraction. Generally, the release rate of a particular metal under acidic conditions is directly influenced by the fraction that is associated with it (Wang et al., 2015). The carbonate-bound fraction is greatly influenced by variation in the $\mathrm{pH}$, and the metal bound to it can be easily extracted by solidstate dissolution (Yang et al., 2019). The study of Han and Banin (1995) found that all the carbonates in calcareous soil with $10-20 \%$ of carbonates can be dissolved with a NaOAc-HOAc solution at pH 5.5. Therefore, the total release of metals bound to carbonate fraction can be expected, even with weak acids while the utilization of a strong acid will only increase the rate of dissolution. Thus, the high Cu content found in the carbonate fraction reflects the suitability of acid leaching for $\mathrm{Cu}$ extraction compared to the use of other leaching techniques. In contrast, the concentration of $\mathrm{Pb}$ was comparatively less (10.2 $\mathrm{mg} \mathrm{kg}^{-1}$ ) in the carbonate-bound fraction, while the greatest $\mathrm{Pb}$ concentration ( $800.6 \mathrm{mg} \mathrm{kg}^{-1}$ ) was reported in the residual/silicate fraction. In the residual fraction, metals are captured in crystalline assemblages and release into the environment under natural conditions is uncommon. Generally, ordered silicates including, sheet, chain and network silicates, are less susceptible to dissolution with acids due the high strength of the $\mathrm{Si}-\mathrm{O}$ bond (Terry, 1983). The least amount of $\mathrm{Cu}$ was bound to the exchangeable fraction $\left(24.5 \mathrm{mg} \mathrm{kg}^{-1}\right)$, while $\mathrm{Pb}$ was not detected in that phase. Nickel was primarily observed as bound to the $\mathrm{Fe}-\mathrm{Mn}$ oxide and carbonate-bound fractions (20.2 and $18.3 \mathrm{mg} \mathrm{kg}^{-1}$, respectively). Copper, $\mathrm{Pb}$, and Ni occupied individual fractions in the order of: carbonates $>\mathrm{Fe}-\mathrm{Mn}$ oxides $>$ organic matter $>$ residual $>$ exchangeable for $\mathrm{Cu}$, residual $>$ organic matter $>\mathrm{Fe}-\mathrm{Mn}$ oxides $>$ carbonates for $\mathrm{Pb}$, and $\mathrm{Fe}-\mathrm{Mn}$ oxides $>$ carbonates $>$ residual/silicate for Ni. 
a)

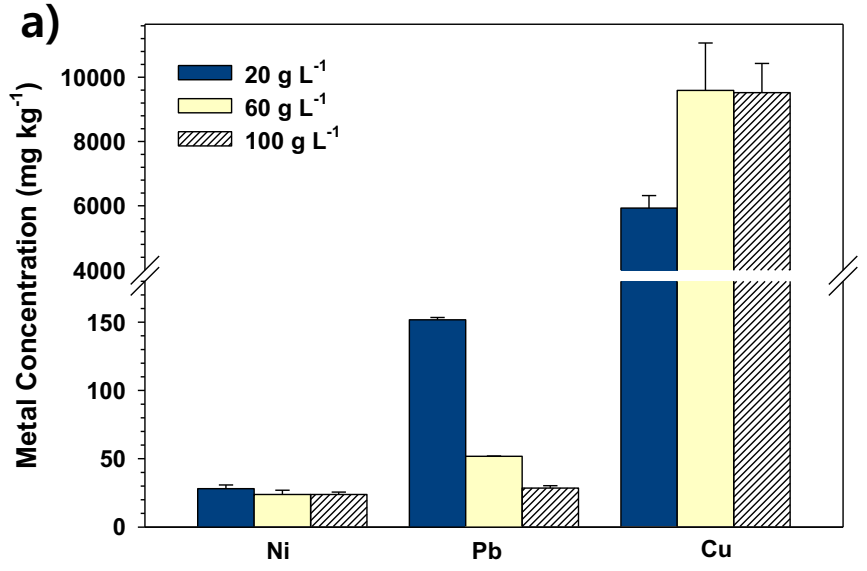

b)

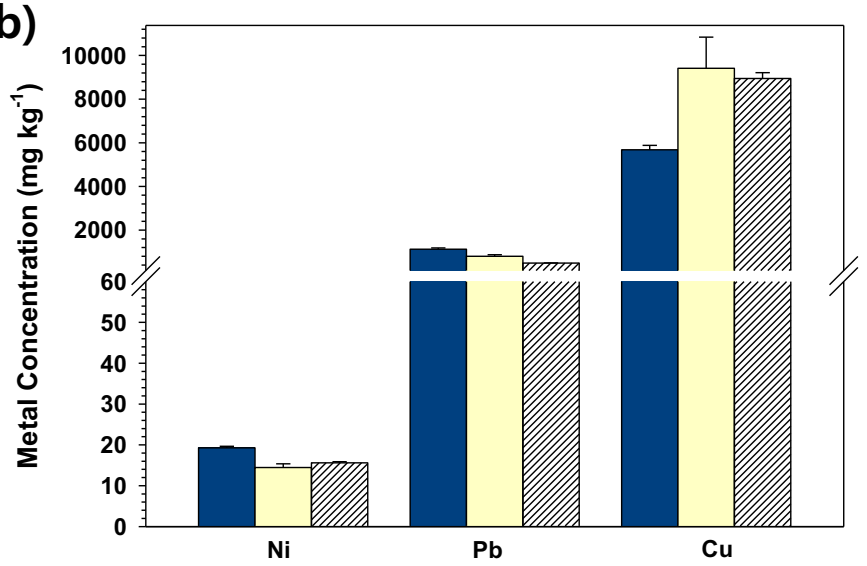

Fig. 3. Optimal solid:liquid (S/L) ratio for metal release from electrical industrial sludge with a) sulfuric and b) malic acid.

(a)

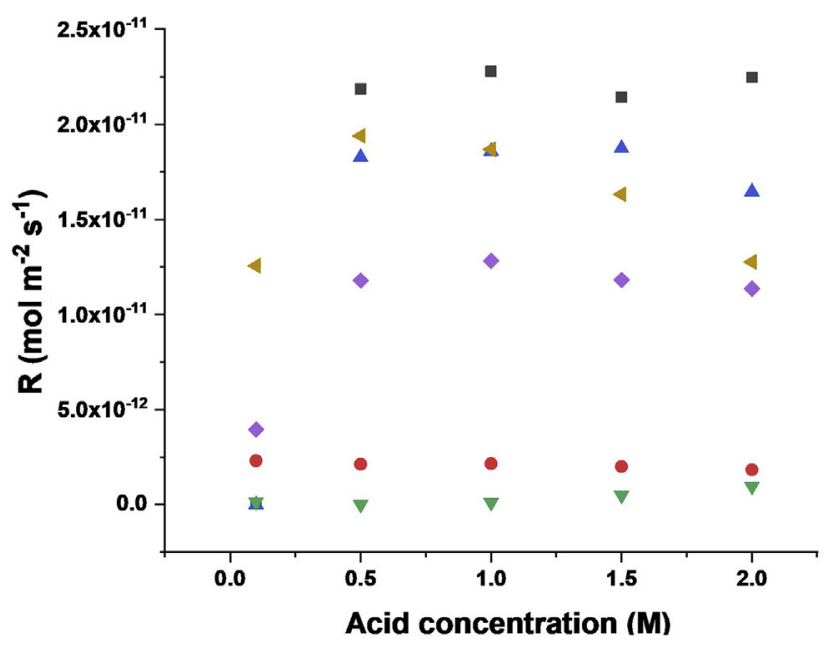

(b)

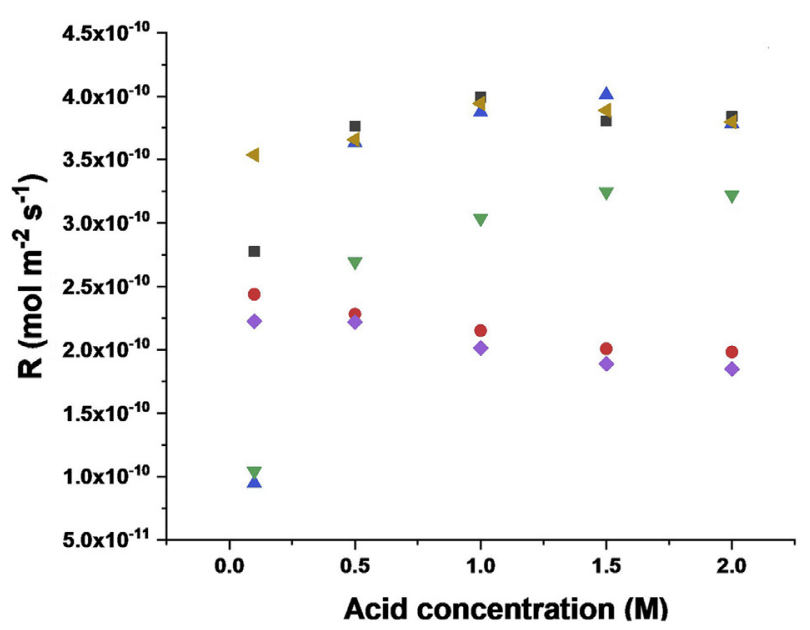

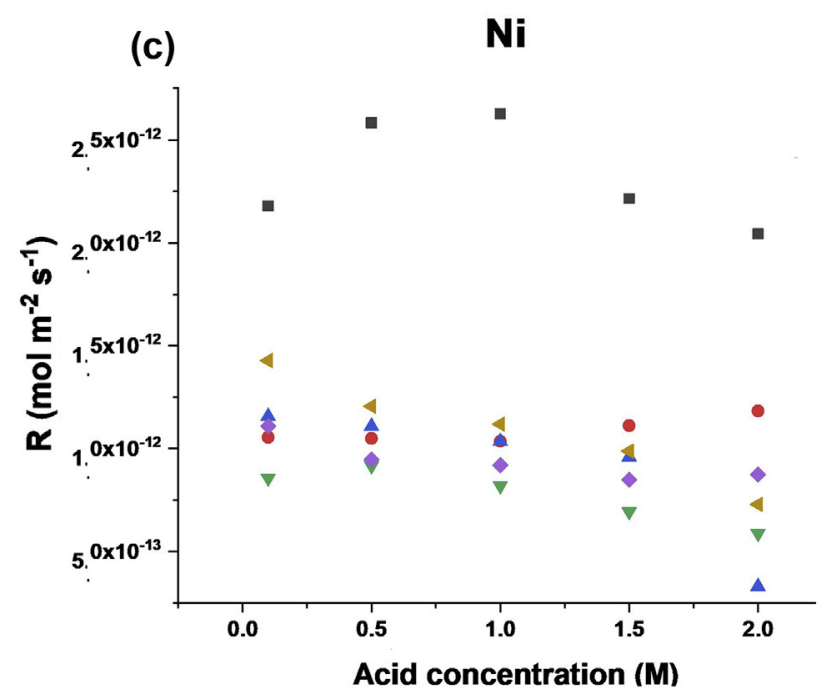

Fig. 4. Release rates for, a) Pb, b) $\mathrm{Cu}$, and c) Ni by different acids under increasing concentrations. 


\subsection{Inorganic and organic acid extractions}

\subsubsection{Best solid to liquid ratio}

As shown in Fig. 3, the maximum release of $\mathrm{Cu}$ was achieved with a $\mathrm{S} / \mathrm{L}$ ratio of $60 \mathrm{~g} \mathrm{~L}^{-1}$ for both sulfuric and malic acids (9592.19 and $9413.97 \mathrm{mg} \mathrm{kg}^{-1}$, respectively). As opposed to the release of $\mathrm{Cu}$, the release of $\mathrm{Pb}$ reached a maximum at the $\mathrm{S} / \mathrm{L}$ ratio of $20 \mathrm{~g} \mathrm{~L}^{-1}$. At that $\mathrm{S} / \mathrm{L}$ ratio, sulfuric acid was responsible for the release of $151.82 \mathrm{mg} \mathrm{kg}^{-1}$ of $\mathrm{Pb}$ while malic acid facilitated the release of $1122.61 \mathrm{mg} \mathrm{kg}^{-1}$ of $\mathrm{Pb}$. Similarly, the release of Ni was highest at a S/L ratio of $20 \mathrm{~g} \mathrm{~L}^{-1}$ for both acids ( 28.13 and $19.28 \mathrm{mg} \mathrm{kg}^{-1}$ for sulfuric and malic acid, respectively).

However, the maximum release of $\mathrm{Cu}$ by both sulfuric and malic acids was achieved at a $\mathrm{S} / \mathrm{L}$ ratio of $60 \mathrm{~g} \mathrm{~L}^{-1}$, while the maximum release of $\mathrm{Pb}$ and $\mathrm{Ni}$ was observed at $20 \mathrm{~g} \mathrm{~L}^{-1}$. Moreover, the handling of electrical industrial sludge at high $\mathrm{S} / \mathrm{L}$ ratios was difficult due to the gluey consistency of the sludge which clogged the filter papers. Therefore, $20 \mathrm{~g} \mathrm{~L}^{-1}$ was considered as the optimal S/L ratio for the majority of heavy metals and it was used to carry out further experiments.

\subsubsection{Release rate}

The Fig. 4 shows the effect of the concentration of each acid on the release rates of $\mathrm{Pb}, \mathrm{Cu}$, and Ni. Nitric acid was responsible for the maximum release of $\mathrm{Pb}$ and $\mathrm{Ni}$. The release of $\mathrm{Pb}$ exceeded $\mathrm{a}$ rate of $2.0 \times 10^{-11} \mathrm{~mol} \mathrm{~m}^{-2} \mathrm{~s}^{-1}$ at nitric acid concentrations above $0.5 \mathrm{~mol} \mathrm{~L}^{-1}$. Similarly, the highest release rate of $\mathrm{Ni}$ was governed by nitric acid. All five concentrations of nitric acid, ranging from 0.1 to $2.0 \mathrm{~mol} \mathrm{~L}^{-1}$, yielded release of $\mathrm{Ni}$ above the rate of $2.0 \times 10^{-12} \mathrm{~mol} \mathrm{~m}^{-2} \mathrm{~s}^{-1}$. The release rates of $\mathrm{Cu}$ from electrical industrial sludge by nitric, phosphoric, and citric acids were shown to be comparatively similar at concentrations above $0.5 \mathrm{~mol} \mathrm{~L}^{-1}$.

Nitric, phosphoric, and citric acids led to considerably higher metal release rates than the other three acids at the concentration of $1.0 \mathrm{~mol} \mathrm{~L}^{-1}$ (Fig. 5). However, nitric acid at $1.0 \mathrm{~mol} \mathrm{~L}^{-1}$ concentration yielded the highest release rates for all three metals examined. The cumulative metal release rate from nitric acid was $4.25 \times 10^{-10} \mathrm{~mol} \mathrm{~m}^{-2} \mathrm{~s}^{-1}$, and the rates for individual metals, $\mathrm{Pb}, \mathrm{Cu}$, and Ni were $2.28 \times 10^{-11}$,
$3.99 \times 10^{-10}$, and $2.63 \times 10^{-12} \mathrm{~mol} \mathrm{~m}^{-2} \mathrm{~s}^{-1}$, respectively. The sum of the release rates of metals from electrical industrial sludge by $1.0 \mathrm{~mol} \mathrm{~L}^{-1}$ acid increased in the order of: malic $<$ sulfuric $<$ acetic $<$ phosphoric $<$ citric $<$ nitric.

\subsubsection{Assessment of the proton- and ligand-promoted release of metals}

It is useful to employ an enhancement factor to compare the rate of dissolution of elements by different acids. Previous studies have shown that metal release from soils and minerals in the presence of organic and inorganic acids is governed by both proton- and ligand-promoted mechanisms (Rajapaksha et al., 2012; Hamer et al., 2003). Both protons and ligands are capable of releasing metals by desorbing them from different fractions of the sludge. Ion exchange is the main protonpromoted mechanism for metal release. Moreover, high concentrations of protons from strong acids can dissolve the matrix associated with metals, resulting in metal release. On the other hand, ligands from inorganic acids comprise of various functional groups which have the capacity to make complexes with metals and facilitate metal release (Neale et al., 1997). Therefore, the total rate of metal release $\left(R_{T}\right)$ is equal to the sum of the rates for proton-promoted release $\left(R_{H}\right)$ and ligandpromoted release $\left(R_{L}\right)$ (Welch and Ullman, 1996).

$R_{T}=R_{H}+R_{L}$

Eq. (2) was used to calculate $\log \mathrm{R}_{\mathrm{T}}$ for the release of each metal by both organic and inorganic acids at $\mathrm{pH} 1$. To do so, the $\mathrm{pH}$ of each organic and inorganic acid used under each concentration was calculated by solution $\mathrm{H}^{+}$concentration. The values obtained for $\mathrm{R}_{\mathrm{T}}$ at these concentrations of acids were converted to a log scale and plotted against the calculated $\mathrm{pH}$ value of each acid at that particular concentration (Fig. 6). Linear fitting was done for resulting curves and rate constant $\left(\log K_{T}\right)$ and reaction order $\left(n_{T}\right)$ in Eq. (2) were calculated using the intercept $\left(\log \mathrm{K}_{\mathrm{T}}\right)$ and slope $\left(\mathrm{n}_{\mathrm{T}}\right)$ of the fitted curves. No ligand was integrated into nitric acid, thus, it was assumed that $\mathrm{R}_{\mathrm{T}}$ from nitric acid was only generated from proton-promoted mechanisms $\left(R_{H}\right) ; R_{L}$ was calculated using Eq. (3). All the values obtained for $\log \mathrm{K}_{\mathrm{T}}, \mathrm{nT}, \mathrm{R}_{\mathrm{T}}$, and $\mathrm{R}_{\mathrm{L}}$ are presented in Table 3 .

At $\mathrm{pH} 1$, the highest rate for $\mathrm{Pb}$ release is driven by malic acid $\left(3.90 \times 10^{-11} \mathrm{~mol} \mathrm{~m}^{-2} \mathrm{~s}^{-1}\right)$. Similarly, malic acid poses the highest

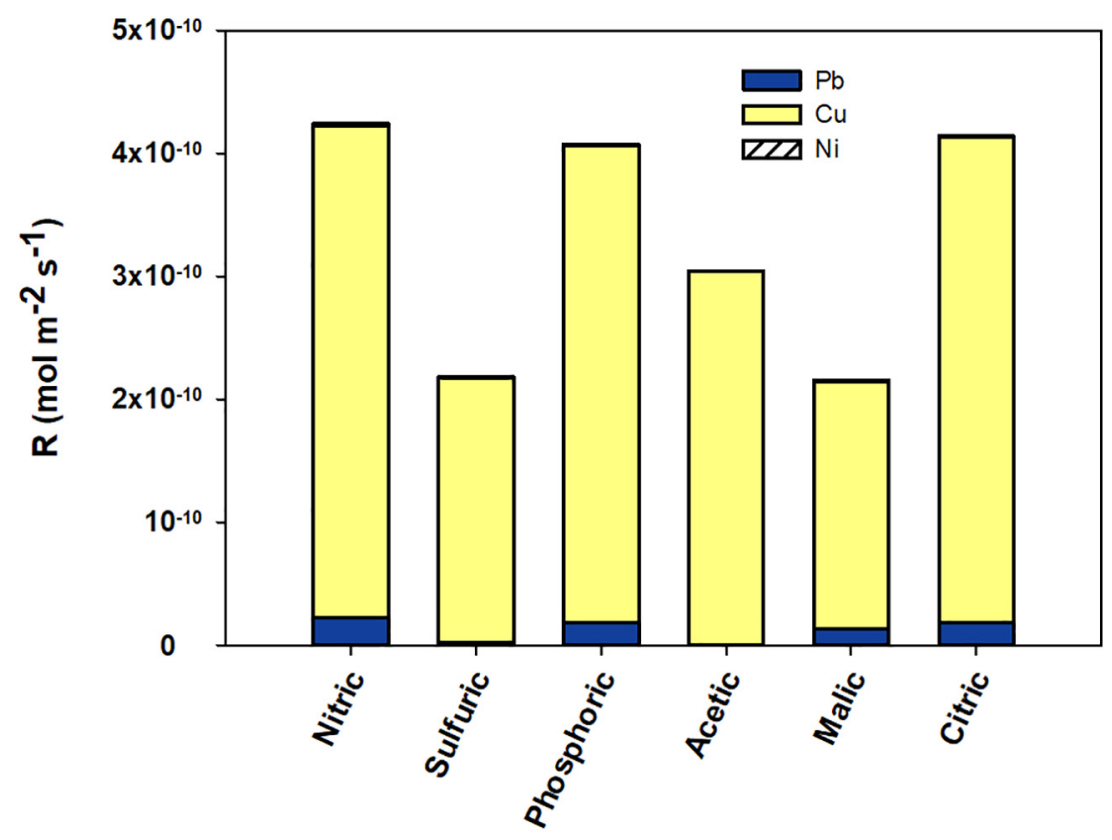

Fig. 5. Cumulative release rates for $\mathrm{Pb}, \mathrm{Cu}$, and $\mathrm{Ni}$ from electrical industrial sludge in the presence of inorganic and organic acid solutions at 1.0 mol $\mathrm{L}^{-1}$ concentration. 
(a) Nitric

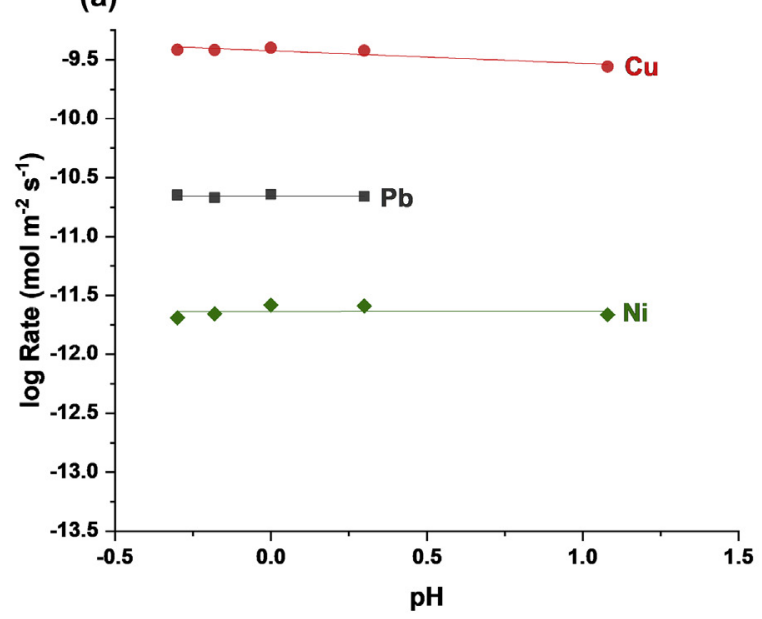

(c) Phosphoric

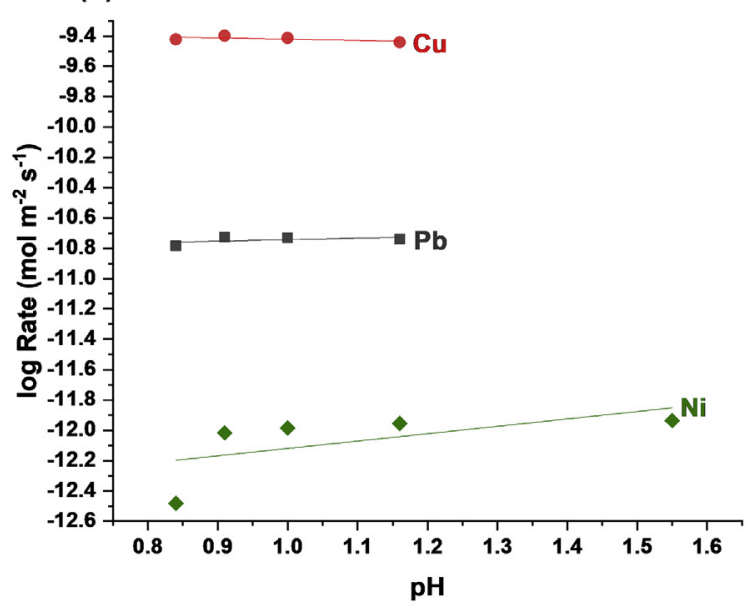

Malic

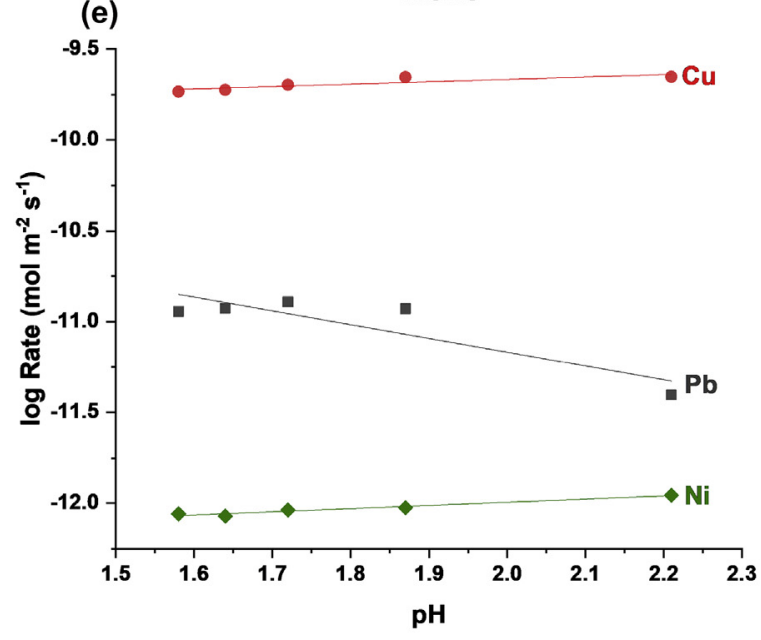

Sulfuric

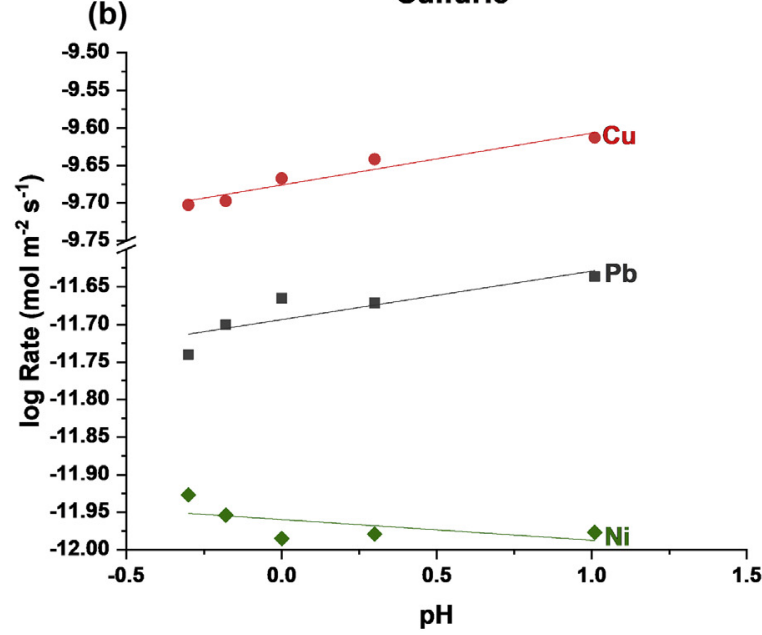

Acetic
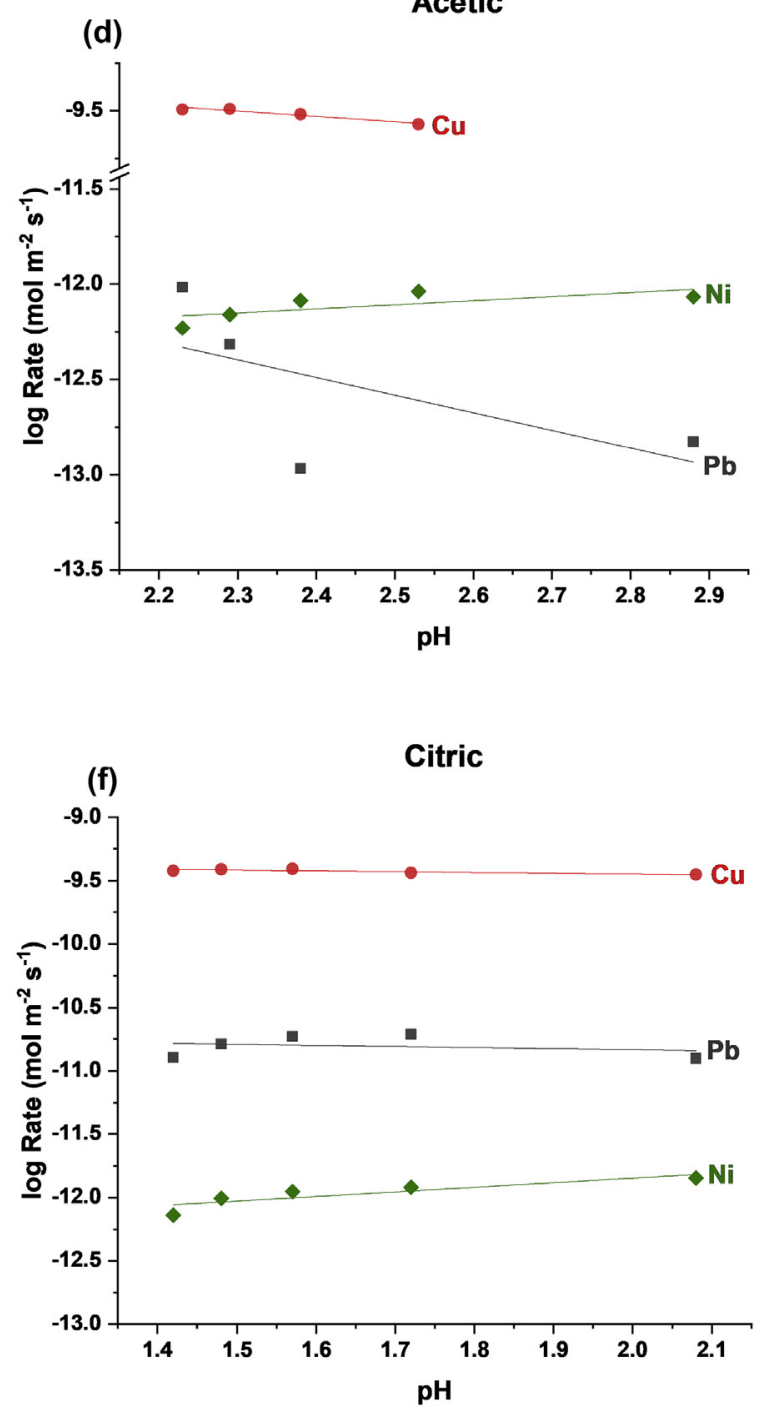

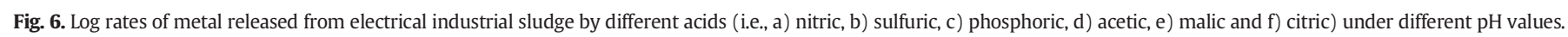

$R_{L}$ and $R_{T} / R_{H}$ for Pb release. The presence of a high $R_{T} / R_{H}$ ratio reveals that the release of $\mathrm{Pb}$ by malic acid is driven by ligand-promoted mechanisms rather than proton-promoted mechanisms. Malic acid is known to increase dissolving efficiencies of divalent metal ions by chelating them and forming surface complexes (Seo and Kim, 2016; Mckenzie et al., 1987). Malic acid has the ability to make 
Table 3

Rate constant $\left(\mathrm{K}_{\mathrm{T}}\right)$, reaction order $\left(\mathrm{n}_{\mathrm{T}}\right)$, total rate of dissolution $\left(\mathrm{R}_{\mathrm{T}}\right)$, ligand-promoted dissolution $\left(\mathrm{R}_{\mathrm{L}}\right)$, and $\mathrm{R}_{\mathrm{T}} / \mathrm{R}_{\mathrm{H}}$ ratio for $\mathrm{Pb}, \mathrm{Cu}$, and $\mathrm{Ni}$ released from electrical industrial sludge in the presence of different inorganic and organic acids.

\begin{tabular}{|c|c|c|c|c|c|}
\hline \multirow[t]{2}{*}{ Acid } & \multirow[t]{2}{*}{$\log K_{T}$} & \multirow[t]{2}{*}{$\mathrm{n}_{\mathrm{T}}$} & $\mathrm{R}_{\mathrm{T}}$ & $\mathrm{R}_{\mathrm{L}}$ & \multirow[t]{2}{*}{$\mathrm{R}_{\mathrm{T}} / \mathrm{R}_{\mathrm{H}}$} \\
\hline & & & \multicolumn{2}{|c|}{$\begin{array}{l}\mathrm{mol} \mathrm{m}^{-2} \mathrm{~s}^{-1} \times \\
10^{-11}\end{array}$} & \\
\hline \multicolumn{6}{|l|}{ Release of $\mathrm{Pb}$} \\
\hline Nitric acid & -10.66 & -0.01 & 2.18 & 0.00 & 1.00 \\
\hline Sulfuric acid & -11.69 & 0.06 & 0.23 & -1.95 & 0.11 \\
\hline Phosphoric acid & -10.84 & 0.10 & 1.81 & -0.37 & 0.83 \\
\hline Acetic acid & -10.27 & -0.92 & 0.64 & -1.55 & 0.29 \\
\hline Malic acid & -9.65 & -0.76 & 3.90 & 1.71 & 1.79 \\
\hline Citric acid & -10.67 & -0.08 & 1.78 & -0.40 & 0.82 \\
\hline \multicolumn{6}{|l|}{ Release of $\mathrm{Cu}$} \\
\hline Nitric acid & -9.42 & -0.11 & 29.48 & 0.00 & 1.00 \\
\hline Sulfuric acid & -9.68 & 0.07 & 24.74 & -4.74 & 0.84 \\
\hline Phosphoric acid & -9.34 & -0.08 & 38.07 & 8.59 & 1.29 \\
\hline Acetic acid & -8.86 & -0.28 & 72.62 & 43.14 & 2.46 \\
\hline Malic acid & -9.93 & 0.13 & 15.96 & -13.52 & 0.54 \\
\hline Citric acid & -9.32 & -0.06 & 41.36 & 11.88 & 1.40 \\
\hline \multicolumn{6}{|l|}{ Release of $\mathrm{Ni}$} \\
\hline Nitric acid & -11.64 & 0.00 & 0.23 & 0.00 & 1.00 \\
\hline Sulfuric acid & -11.96 & -0.03 & 0.10 & -0.13 & 0.44 \\
\hline Phosphoric acid & -12.61 & 0.49 & 0.08 & -0.16 & 0.32 \\
\hline Acetic acid & -12.64 & 0.21 & 0.04 & -0.20 & 0.16 \\
\hline Malic acid & -12.34 & 0.17 & 0.07 & -0.17 & 0.29 \\
\hline Citric acid & -12.57 & 0.36 & 0.06 & -0.17 & 0.27 \\
\hline
\end{tabular}

divalent metal-Mal complexes by acting as a chelator (Seo and Kim, 2016). In this study, the Pb-Mal complex was formed in the presence of $\mathrm{Pb}^{2+}$. The two complexes are produced from the chelating reaction of $\mathrm{Pb}$ with malic acid, as $\mathrm{Pb}-\mathrm{HMal}$ and $\mathrm{Pb}\left(\mathrm{H}_{2} \mathrm{Mal}\right)_{2}$. Moreover, each of the malic acid molecules can release two $\mathrm{H}^{+}$ions by a twostep process, as mentioned in Eqs. (4) and (5) (Li et al., 2010), enhancing the further release of $\mathrm{Pb}$ by proton-related mechanisms.

$\mathrm{H}_{3}-\mathrm{Mal} \rightleftharpoons \mathrm{H}_{2}-\mathrm{Mal}^{-}+\mathrm{H}^{+} ; \mathrm{pKa}_{1}=3.5$

$\mathrm{H}_{2}-\mathrm{Mal}^{-} \rightleftharpoons \mathrm{H}^{-\mathrm{Mal}^{2-}}+\mathrm{H}^{+} ; \mathrm{pKa}_{2}=5.1$

However, at $\mathrm{pH} 1$, the lowest rate of $\mathrm{Pb}$ release was observed at $0.23 \times 10^{-11} \mathrm{~mol} \mathrm{~m}^{-2} \mathrm{~s}^{-1}$, of the reaction with sulfuric acid. Lead is mainly associated with residual/silicate bound fraction (Table 2) and sulfuric acid has a limited reaction with $\mathrm{Pb}$ containing silicates due to the solubility limits of sulfates of Pb (Terry, 1983).

Conversely, acetic acid produced the greatest rate of release of $\mathrm{Cu}$ $\left(72.62 \times 10^{-11} \mathrm{~mol} \mathrm{~m}^{-2} \mathrm{~s}^{-1}\right)$ at $\mathrm{pH} 1$. The calculated enhancement factor indicates that $\mathrm{Cu}$ release is facilitated by both ligand- and proton-promoted mechanisms $\left(\mathrm{R}_{\mathrm{L}}=43.14 \times 10^{-11} \mathrm{~mol} \mathrm{~m}^{-2} \mathrm{~s}^{-1}\right.$ and $\mathrm{R}_{\mathrm{T}} / \mathrm{R}_{\mathrm{H}}=2.46$ ). Ionization of acetic acid releases $\mathrm{H}^{+}$(Eq. (6)), facilitating the release of $\mathrm{Cu}$ from sludge through proton-promoted mechanisms.

$\mathrm{CH}_{3} \mathrm{COOH} \rightleftharpoons \mathrm{H}^{+} \mathrm{CH}_{3} \mathrm{COO}^{-} ; \mathrm{pKa}=4.75$

Moreover, acetic acid contains ligands that enhance the release rate of $\mathrm{Cu}$, in a similar manner as in malic acid (Eq. (7)).

$\mathrm{Cu}^{2+}+2 \mathrm{CH}_{3} \mathrm{COOH} \rightleftharpoons\left(\mathrm{CH}_{3} \mathrm{COO}\right)_{2} \mathrm{Cu}+2 \mathrm{H}^{+}$

The concentration and activity of ligands are proportional to the release rate of metals (Rajapaksha et al., 2012). However, in this study, the release rates of $\mathrm{Pb}$ and $\mathrm{Cu}$ were promoted in different ways by the ligands from acetic, malic, and citric acids. Therefore, the nature of the ligand played a major role in the release of $\mathrm{Pb}$ and $\mathrm{Cu}$ from sludge. Moreover, chelating agents such as EDTA (Ethylenediamine tetraacetic acid), DTPA (diethylenetriamine pentaacetic acid) and NTA (nitriloacetic acid) have been shown to have better performance in the removal of heavy metals from waste materials by making strong metal-ligand complexes (Zhang et al., 2015a). Among them, EDTA is the most widely used chelating agent and studies of Zhang et al. (2015b) and Zhang et al. (2016) have shown the high affinity of EDTA for $\mathrm{Cu}^{2+}$ in the removal of $\mathrm{Cu}$ from anammox granules. However, NTA has been reported as class II carcinogen while DTPA has been identified as a toxicant with potential carcinogenic activity (Zou et al., 2009). Although, EDTA has no known carcinogenic effects, it can induce cytotoxicity and weak genotoxicity. Moreover, EDTA has been reported to cause reproductive and developmental anomalies in animals after oral exposure (Lanigan and Yamarik, 2002). However, organic acids such as acetic and citric acids are considered as non-toxic and renewable compounds which can be easily biodegraded (Halpern et al., 2014; Chamarro et al., 2001). Therefore, the use of organic acids to chelate metals in sludge can be considered a feasible and effective technique when considering environment and human health risks. Moreover, unlike other chelating agents, further enhancement of metal removal can be expected by proton-related mechanisms resulting from the use of organic acids.

Unlike $\mathrm{Pb}$ and $\mathrm{Cu}$, nitric acid facilitated the highest rate of release for $\mathrm{Ni}$, at the rate of $0.23 \times 10^{-11} \mathrm{~mol} \mathrm{~m}^{-2} \mathrm{~s}^{-1}$. In contrast to the release of the other two metals studied, the release of Ni was not attributed to ligand-promoted mechanisms. As an inorganic acid, the nitric acid molecule does not contain chelating groups that assist ligand-promoted mechanisms in the release of $\mathrm{Ni}$. In an aqueous solution, the complete ionization of nitric acid takes place, releasing $\mathrm{H}^{+}$ions as shown in Eq. (8). This results in ion exchange, a proton-promoted mechanism, releasing Ni from electrical industrial sludge.

$\mathrm{HNO}_{3(\mathrm{aq})} \rightarrow \mathrm{H}^{+}{ }_{(\mathrm{aq})}+\mathrm{NO}_{3}^{-}(\mathrm{aq})$

\section{Conclusions}

This study demonstrates that electrical industrial sludge is mainly composed of $\mathrm{Cu}$ and $\mathrm{Pb}$ as heavy metals, and $\mathrm{Ni}$ is also present in small concentrations. Copper is predominantly found in the carbonate-bound fractions, emphasizing the feasibility of the acid leaching technique for recovering $\mathrm{Cu}$ from electrical industrial sludge. Lead, on the other hand, is mainly confined to the residual fraction, while $\mathrm{Ni}$ is primarily bound to the $\mathrm{Fe}-\mathrm{Mn}$ oxide-bound fraction. The optimal S/L ratio for maximum release of $\mathrm{Cu}$ is $60 \mathrm{~g} \mathrm{~L}^{-1}$ for both sulfuric and malic acids. In contrast, $20 \mathrm{~g} \mathrm{~L}^{-1}$ resulted in the greatest release of $\mathrm{Pb}$ and $\mathrm{Ni}$ by sulfuric and malic acids. Maximum cumulative rates of release for $\mathrm{Pb}, \mathrm{Cu}$, and $\mathrm{Ni}$ at $1.0 \mathrm{~mol} \mathrm{~L}^{-1}$ acid concentration were facilitated by nitric acid and it is the optimum leaching solution for separation of all three examined metals from the sludge. At $\mathrm{pH} 1$, the highest rate of release for $\mathrm{Pb}$ was with malic acid, while acetic acid was responsible for the highest release observed for $\mathrm{Cu}$. The high rate of metal release by organic acids is attributed to the ligand-promoted mechanisms, which enhance the release of metal ions from the sludge forming complexes. In contrast to $\mathrm{Pb}$ and $\mathrm{Cu}$, the rate of release for $\mathrm{Ni}$ was highest with nitric acid at $\mathrm{pH} 1$, indicating proton-promoted mechanisms, mainly ion exchange. Therefore, knowledge of the release mechanism of heavy metals from waste materials is useful for determining the best acid type and concentration for efficient and effective recovery of metals. Further studies targeting different types of industrial sludge with dissimilar characteristics are necessary to reveal the exact mechanisms of metal release by acids.

\section{Acknowledgements}

Authors thank Dr. Athula Wijayasinghe, National Institute of Fundamental Studies, Sri Lanka, for providing BET surface area analysis, and the Instrument Centre, University of Sri Jayewardenepura, Sri Lanka, 
for providing facilities for XRD and FTIR analysis. The Research Council of the University of Sri Jayewardenepura, Sri Lanka, is acknowledged for providing financial support for the study (Grant No. ASP/01/RE/ $\mathrm{SCI} / 2017 / 82$ ) and the US-Sri Lanka Fulbright Commission for providing funding to NR during the field-phase of the project.

\section{References}

Al-Harahsheh, M., Al-Nu'airat, J., Al-Otoom, A., Al-Jabali, H., Al-Zoubi, M., 2018. Treatments of electric arc furnace dust and halogenated plastic wastes: a review. J. Environ. Chem. Eng., 102856 https://doi.org/10.1016/j.jece.2018.102856.

Ali, S.W., Mirza, M.L., Bhatti, T.M., 2015. Removal of Cr (VI) using iron nanoparticles supported on porous cation-exchange resin. Hydrometallurgy 157, 82-89. https://doi. org/10.1016/j.hydromet.2015.07.013.

Anderson, J.M., Ingram, J., 1989. Tropical Soil Biology and Fertility. CAB international Wallingford.

Anjithan, K., Athapattu, B., Ratnayake, N., Udamulla, L., 2015. Sludge of Water Treatment Works: Are Disposal Practices Sustainable. Sri Lanka Association for the Advancement of Science. University of Sri Jayewardenepura.

Armienta, M., Rodríguez, R., Ceniceros, N., Juarez, F., Cruz, O., 1996. Distribution, origin and fate of chromium in soils in Guanajuato, Mexico. Environ. Pollut. 91, 391-397. https:// doi.org/10.1016/0269-7491(95)00040-2.

Azbar, N., Keskin, T., Yuruyen, A., 2008. Enhancement of biogas production from olive mill effluent (OME) by co-digestion. Biomass Bioenergy 32, 1195-1201. https://doi.org/ 10.1016/j.biombioe.2008.03.002.

Barakat, M., 2011. New trends in removing heavy metals from industrial wastewater. Arab. J. Chem. 4, 361-377. https://doi.org/10.1016/j.arabjc.2010.07.019.

Barrera, K., Briso, A., Ide, V., Martorana, L., Montes, G., Basualto, C., Borrmann, T., Valenzuela, F., 2017. Treatment of acidic mine drainage in an adsorption process using calcium silicate modified with Fe (III). Hydrometallurgy 172, 19-29. https:// doi.org/10.1016/j.hydromet.2017.06.016.

Battsengel, A., Batnasan, A., Narankhuu, A., Haga, K., Watanabe, Y., Shibayama, A., 2018. Recovery of light and heavy rare earth elements from apatite ore using sulphuric acid leaching, solvent extraction and precipitation. Hydrometallurgy https://doi.org/ 10.1016/j.hydromet.2018.05.024.

Brewer, G.J., 2010. Copper toxicity in the general population. Clin. Neurophysiol. 121, 459-460. https://doi.org/10.1016/j.clinph.2009.12.015.

Brocato, J., Costa, M., 2017. Nickel toxicity and carcinogenesis. The Biological Chemistry of Nickel. 10, p. 27

Chamarro, E., Marco, A., Esplugas, S., 2001. Use of Fenton reagent to improve organic chemical biodegradability. Water Res. 35, 1047-1051. https://doi.org/10.1016/ S0043-1354(00)00342-0.

Cui, X., Zhang, Y., Wu, X., Liu, C., 2010. The investigation of the alleviated effect of copper toxicity by exogenous nitric oxide in tomato plants. Plant Soil Environ. 56, $274-281$. https://doi.org/10.17221/98/2009-PSE.

Epa, 1992. Toxicity Characteristic Leaching Procedure. Method 1311. Test Methods for Evaluating Solid Waste. US Environmental Protection Agency, Washington DC.

Ghorpade, A., Ahammed, M.M., 2017. Water treatment sludge for removal of heavy metals from electroplating wastewater. Environ. Eng. Res. 23, 92-98. https://doi. org/10.4491/eer.2017.065.

Habashi, F., 2005. A short history of hydrometallurgy. Hydrometallurgy 79, 15-22. https:// doi.org/10.1016/j.hydromet.2004.01.008.

Halpern, J.M., Urbanski, R., Weinstock, A.K., Iwig, D.F., Mathers, R.T., Von Recum, H.A. 2014. A biodegradable thermoset polymer made by esterification of citric acid and glycerol. J. Biomed. Mater. Res. A 102, 1467-1477. https://doi.org/10.1002/jbm. a.34821.

Hamer, M., Graham, R., Amrhein, C., Bozhilov, K., 2003. Dissolution of ripidolite (Mg, Fechlorite) in organic and inorganic acid solutions. Soil Sci. Soc. Am. J. 67, 654-661. https://doi.org/10.2136/sssaj2003.6540.

Han, F., Banin, A., 1995. Selective sequential dissolution techniques for trace metals in arid-zone soils: the carbonate dissolution step. Commun. Soil Sci. Plant Anal. 26, 553-576. https://doi.org/10.1080/00103629509369318.

Hossain, M.S., Al-Hamadani, S.M., Rahman, M.T., 2015. E-waste: a challenge for sustainable development. J. Health Pollut. 5, 3-11. https://doi.org/10.5696/2156-9614-5-9.3.

Huyen, P.T., Dang, T., Tung, M.T., Huyen, N.T., Green, T., Roy, S., 2016. Electrochemical copper recovery from galvanic sludge. Hydrometallurgy 164, 295-303. https://doi.org/ 10.1016/j.hydromet.2016.06.028.

Lanigan, R., Yamarik, T., 2002. Final report on the safety assessment of EDTA, calcium disodium EDTA, diammonium EDTA, dipotassium EDTA, disodium EDTA, TEA-EDTA, tetrasodium EDTA, tripotassium EDTA, trisodium EDTA, HEDTA, and trisodium HEDTA. Int. J. Toxicol. 21, 95-142. https://doi.org/10.1080/10915810290096522.

Li, L., Ge, J., Chen, R., Wu, F., Chen, S., Zhang, X., 2010. Environmental friendly leaching reagent for cobalt and lithium recovery from spent lithium-ion batteries. Waste Manag. 30, 2615-2621. https://doi.org/10.1016/j.wasman.2010.08.008.

Li, L., Wu, H., Van Gestel, C.A., Peijnenburg, W.J., Allen, H.E., 2014. Soil acidification increases metal extractability and bioavailability in old orchard soils of Northeast Jiaodong Peninsula in China. Environ. Pollut. 188, 144-152. https://doi.org/10.1016/ j.envpol.2014.02.003.

Liu, F., Liu, Z., Li, Y., Liu, Z., Li, Q., Zeng, L., 2016. Extraction of gallium and germanium from zinc refinery residues by pressure acid leaching. Hydrometallurgy 164, 313-320. https://doi.org/10.1016/j.hydromet.2016.06.006.

Lobato, N.C.C., Villegas, E.A., Mansur, M.B., 2015. Management of solid wastes from steelmaking and galvanizing processes: a brief review. Resour. Conserv. Recycl. 102, 49-57. https://doi.org/10.1016/j.resconrec.2015.05.025.
Lu, D., Cao, O., Li, X., Cao, X., Luo, F., Shao, W., 2009. Kinetics and equilibrium of Cu (II) adsorption onto chemically modified orange peel cellulose biosorbents. Hydrometallurgy 95, 145-152. https://doi.org/10.1016/j.hydromet.2008.05.008.

Mckenzie, D.I., Denys, L., Buchanan, A., 1987. The solubilization of nickel, cobalt and iron from laterites by means of organic chelating acids at low pH. Int. J. Miner. Process. 21, 275-292. https://doi.org/10.1016/0301-7516(87)90059-7.

Medi, H.Z., Chromu, Z.A., Kalov, Z.G., 2006. Hydrometallurgical route for copper, zinc and chromium recovery from galvanic sludge. Acta Metall. Slovaca 12, 293-302.

Neale, C.N., Bricka, R., Chao, A.C., 1997. Evaluating acids and chelating agents for removing heavy metals from contaminated soils. Environ. Prog. 16, 274-280. https://doi.org/ 10.1002/ep.3300160416.

Nemerow, N.L., 2010. Industrial Waste Treatment: Contemporary Practice and Vision for the Future. Elsevier, Burlington, MA 01803, USA.

Pecht, M.G., Ali, I., Carlson, A., 2018. Phthalates in electronics: the risks and the alternatives. IEEE Access 6, 6232-6242. https://doi.org/10.1109/ACCESS.2017.2778950.

Pérez-Belis, V., Bovea, M., Ibáñez-Forés, V., 2015. An in-depth literature review of the waste electrical and electronic equipment context: trends and evolution. Waste Manag. Res. 33, 3-29. https://doi.org/10.1177/0734242X14557382.

Rajapaksha, A.U., Vithanage, M., Oze, C., Bandara, W., Weerasooriya, R., 2012. Nickel and manganese release in serpentine soil from the Ussangoda Ultramafic Complex, Sri Lanka. Geoderma 189, 1-9. https://doi.org/10.1016/j.geoderma.2012.04.019.

Ried, M., 1988. Heavy Metal Removal From Sewage Sludge: Practical Experiences With Acid Treatment. Pretreatment in Chemical Water and Wastewater Treatment. Springer, Berlin, Heidelberg.

Seidel, A., Zimmels, Y., Armon, R., 2001. Mechanism of bioleaching of coal fly ash by Thiobacillus thiooxidans. Chem. Eng. J. 83, 123-130. https://doi.org/10.1016/S13858947(00)00256-4

Seo, B., Kim, S., 2016. Cobalt extraction from tungsten carbide-cobalt (WC-Co) hard metal scraps using malic acid. Int. J. Miner. Process. 151, 1-7. https://doi.org/10.1016/j. minpro.2016.04.002.

Shemi, A., Ndlovu, S., Sibanda, V., Van Dyk, L., 2015. Extraction of alumina from coal fly ash using an acid leach-sinter-acid leach technique. Hydrometallurgy 157, 348-355. https://doi.org/10.1016/j.hydromet.2015.08.023.

Silva, A.C., Mello-Castanho, S., Guitian, F., Montero, I., Esteban-Cubillo, A., Sobrados, I., Sanz, J., Moya, J.S., 2008. Incorporation of galvanic waste $(\mathrm{Cr}, \mathrm{Ni}, \mathrm{Cu}, \mathrm{Zn}, \mathrm{Pb})$ in a soda-lime-borosilicate glass. J. Am. Ceram. Soc. 91, 1300-1305. https://doi.org/ 10.1111/j.1551-2916.2008.02311.x.

Terazono, A., Murakami, S., Abe, N., Inanc, B., Moriguchi, Y., Sakai, S.-I., Kojima, M. Yoshida, A., Li, J., Yang, J., 2006. Current status and research on E-waste issues in Asia. J. Mater. Cycles Waste Manage. 8, 1-12. https://doi.org/10.1007/s10163-0050147-0.

Terry, B., 1983. The acid decomposition of silicate minerals part I. Reactivities and modes of dissolution of silicates. Hydrometallurgy 10, 135-150. https://doi.org/10.1016/ 0304-386X(83)90002-6.

Tessier, A., Campbell, P.G., Bisson, M., 1979. Sequential extraction procedure for the speciation of particulate trace metals. Anal. Chem. 51, 844-851. https://doi.org/10.1021/ ac50043a017.

Tireli, A.A., Do Rosário Guimarães, I., De Souza Terra, J.C., Da Silva, R.R., Guerreiro, M.C. 2015. Fenton-like processes and adsorption using iron oxide-pillared clay with magnetic properties for organic compound mitigation. Environ. Sci. Pollut. Res. 22, 870-881. https://doi.org/10.1007/s11356-014-2973-X.

Tou, F., Yang, Y., Feng, J., Niu, Z., Pan, H., Qin, Y., Guo, X., Meng, X., Liu, M., Hochella, M.F. 2017. Environmental risk implications of metals in sludges from waste water treatment plants: the discovery of vast stores of metal-containing nanoparticles. Environ Sci. Technol. 51, 4831-4840. https://doi.org/10.1021/acs.est.6b05931.

Tsai, L., Fang, H., Lin, J., Chen, C., Tsai, F., 2009. Recovery and stabilization of heavy metal sludge ( $\mathrm{Cu}$ and $\mathrm{Ni}$ ) from etching and electroplating plants by electrolysis and sintering. Sci. China, Ser. B: Chem. 52, 644-651. https://doi.org/10.1007/s11426009-0047-6.

Vemic, M., Bordas, F., Guibaud, G., Comte, S., Joussein, E., Lens, P., Hullebusch, E.V., 2016 Acid extraction of molybdenum, nickel and cobalt from mineral sludge generated by rainfall water at a metal recycling plant. Environ. Technol. 37, 630-639. https:// doi.org/10.1080/09593330.2015.1075601.

Walawalkar, M. Nichol, C.K., Azimi, G, 2016. Process investigation of the acid leaching of rare earth elements from phosphogypsum using $\mathrm{HCl}, \mathrm{HNO}$, and $\mathrm{H} 2 \mathrm{SO} 4$. Hydrometallurgy 166, 195-204. https://doi.org/10.1016/j.hydromet.2016.06.008.

Wang, Z., Wang, Y., Zhao, P., Chen, L., Yan, C., Yan, Y., Chi, Q., 2015. Metal release from contaminated coastal sediments under changing $\mathrm{pH}$ conditions: implications for metal mobilization in acidified oceans. Mar. Pollut. Bull. 101, 707-715. https://doi.org/ 10.1016/j.marpolbul.2015.10.026.

Wang, Y., Xiao, L., Liu, H., Qian, P., Ye, S., Chen, Y., 2018. Acid leaching pretreatment on two-stage roasting pyrite cinder for gold extraction and coprecipitation of arsenic with iron. Hydrometallurgy https://doi.org/10.1016/j hydromet.2018.06.008

Welch, S., Ullman, W., 1996. Feldspar dissolution in acidic and organic solutions: compositional and $\mathrm{pH}$ dependence of dissolution rate. Geochim. Cosmochim. Acta 60 2939-2948. https://doi.org/10.1016/0016-7037(96)00134-2.

Yang, L., Wen, T., Wang, L., Miki, T., Bai, H., Lu, X., Yu, H., Nagasaka, T., 2019. The stability of the compounds formed in the process of removal $\mathrm{Pb}$ (II), $\mathrm{Cu}$ (II) and Cd (II) by steelmaking slag in an acidic aqueous solution. J. Environ. Manag. 231, 41-48. https://doi. org/10.1016/j.jenvman.2018.10.028

Yao, Z., Xia, M., Sarker, P.K., Chen, T., 2014. A review of the alumina recovery from coal fly ash, with a focus in China. Fuel 120, 74-85. https://doi.org/10.1016/j. fuel.2013.12.003.

Zhang, Z.-Z., Cheng, Y.-F., Zhou, Y.-H., Buayi, X., Jin, R.-C., 2015a. A novel strategy for accelerating the recovery of an anammox reactor inhibited by copper (II): EDTA washing 
combined with biostimulation via low-intensity ultrasound. Chem. Eng. J. 279, 912-920. https://doi.org/10.1016/j.cej.2015.05.081.

Zhang, Z.-Z., Deng, R., Cheng, Y.-F., Zhou, Y.-H., Buayi, X., Zhang, X., Wang, H.-Z., Jin, R.-C. 2015b. Behavior and fate of copper ions in an anammox granular sludge reactor and strategies for remediation. J. Hazard. Mater. 300, 838-846. https://doi.org/10.1016/j. jhazmat.2015.08.024.

Zhang, Z.-Z., Cheng, Y.-F., Zhou, Y.-H., Buayi, X., Jin, R.-C., 2016. Roles of EDTA washing and $\mathrm{Ca} 2+$ regulation on the restoration of anammox granules inhibited by copper (II). J. Hazard. Mater. 301, 92-99. https://doi.org/10.1016/j.jhazmat.2015.08.036.
Zhou, K., Wang, A., Zhang, D., Zhang, X., Yang, T., 2017. Sulfuric acid leaching of SmCo alloy waste and separation of samarium from cobalt. Hydrometallurgy 174, 66-70. https:// doi.org/10.1016/j.hydromet.2017.09.014.

Zou, Z., Qiu, R., Zhang, W., Dong, H., Zhao, Z., Zhang, T., Wei, X., Cai, X., 2009. The study of operating variables in soil washing with EDTA. Environ. Pollut. 157, 229-236. https:// doi.org/10.1016/j.envpol.2008.07.009. 